\title{
Kesesuaian Pemeriksaan Jamur Antara Pewarnaan Periodic Acid Schiff (PAS) dan Koh Pada Flour Albus Ibu Hamil di RSUD dr. Soetomo Surabaya
}

\author{
Shinta A.P. \\ Universitas Airlangga, shinta.arya99@gmail.com
}

Arthur P.K

Universitas Airlangga

\begin{abstract}
Abstrak
Diperkirakan 70-75\% wanita usia subur mengalami Kandidiasis Vaginalis. Anamnesa, gejala klinis dan pemeriksaan laboratorium penting untuk menegakkan diagnosis kandidiasis vaginalis. Pemeriksaan sekret vagina dapat dilakukan dengan melakukan pemeriksaan langsung atau basah dan pemeriksaan kultur. Pemeriksaan mikroskopik dapat dipakai untuk membuktikan adanya bentuk ragi dari Candida. Metode tersebut merupakan metode sederhana dalam pengerjaannya, dapat diaplikasikan di laboratorium mikrobiologi klinik yang sederhana dan dianggap efektif karena biaya murah dan hasil didapat dalam waktu yang singkat dibandingkan dengan kultur. Pemeriksaan jamur dengan pewarnaan Periodic Acid Schiff (PAS) terlihat lebih jelas daripada menggunakan $\mathrm{KOH}$ karena adanya Periodic Acid, gugus-gugus hidroksil pada polisakarida kompleks dinding sel jamur mengalami oksidasi menjadi aldehida. Aldehida bereaksi dengan reagen Schiff sehingga jamur akan berwarna merah/merah muda. Penelitian ini bertujuan untuk menganalisis kesesuaian pemeriksaan jamur antara pewarnaan Periodic Acid Schiff (PAS) dan $\mathrm{KOH}$ pada flour albus ibu hamil. Penelitian ini merupakan penelitian observasional deskriptif untuk mengetahui adanya kesesuaian Periodic Acid Schiff (PAS) dan $\mathrm{KOH}$ pada flour albus ibu hamil dengan pendekatan cross sectional. Sampel berupa 30 spesimen sekret vagina ibu hamil yang dikirim ke Laboratorium Mikrobiologi Klinik RSUD Dr. Soetomo Surabaya. Penelitian dilakukan pada bulan Juli - Agustus 2019. Terdapat perbedaan signifikan pada pemeriksaan jamur antara pewarnaan Periodic Acid Schiff (PAS) 56,7\% (17 sampel) dan $\mathrm{KOH} \mathrm{20 \%} \mathrm{(6} \mathrm{sampel)} \mathrm{dari} 30$ sampel (p=0,017). Pemeriksaan jamur dengan pewarnaan Periodic Acid Schiff (PAS) lebih baik daripada $\mathrm{KOH}$ karena mendeteksi lebih banyak.
\end{abstract}

Kata kunci: Flour albus, Kehamilan, Periodic Acid Schiff(PAS), KOH.

\begin{abstract}
An estimated 70-75\% of women of childbearing age suffered Kandidiasis Vaginalis. Clinical history, symptoms and laboratory examinations are very important to diagnose candidiasis vaginalis. Vaginal discharge examination can be done by direct or wet, and culture examination. Microscopic examination can be used to prove the existence of yeast form of Candida. This method is simple, can be applied in clinical microbiology laboratory with limited resources and is considered effective because it is cheap and results are obtained in a short time compared to culture. Detection of fungi by Periodic Acid Schiff (PAS) staining is visually better than $\mathrm{KOH}$ due to the presence of Periodic Acid that causes the hydroxyl groups in polysaccharides of fungal cell wall complexes undergo oxidation and turn into aldehydes. Aldehydes react with Schiff's reagent and turn the fungi into red / pink in color. The aim of this study is to analyze the concordance between Periodic Acid Schiff (PAS) staining and $\mathrm{KOH}$ method for fungal detection in flour albus from pregnant women. This research is a descriptive observational study to figure out the suitability of Periodic Acid Schiff (PAS) staining and $\mathrm{KOH}$ method for fungal detection in flour albus from pregnant women with cross sectional approach. Samples were collected in the form of 30 vaginal discharge specimens taken from pregnant women and sent to the Clinical Microbiology Laboratory Dr. Soetomo Surabaya. The study was conducted in July - August 2019. There was a significant
\end{abstract}


difference in fungal detection between Periodic Acid Schiff (PAS) staining (56.7\%, 17 samples) and $20 \% \mathrm{KOH}$ method (6 samples) out of 30 samples ( $\mathrm{p}=0.017)$. Periodic Acid Schiff (PAS) staining detects more fungi when compared to $\mathrm{KOH}$, and therefore is considered as a better method.

Keywords: Flour albus, pregnancy, Periodic Acid Schiff (PAS), KOH.

\section{PENDAHULUAN}

Kandidiasis vaginalis merupakan penyakit pada vagina yang dipengaruhi faktor dari luar dan dalam tubuh (Murtiastutik, 2008). Faktor dari luar tubuh misalnya penggunaan steroid jangka panjang, pemakaian antibiotik spektrum luas, penggunaan estrogen dosis tinggi, dan kontrasepsi. Sedangkan faktor dari dalam tubuh misalnya siklus menstruasi, diabetes melitus tidak terkontrol, disfungsi sel $\mathrm{T}$, kehamilan, dan keadaan hormonal lainnya (Juanda, 1999; Dismukes, 2003; Brooks, 2007).

Kandidiasis vaginalis merupakan salah satu bentuk infeksi pada vagina yang umumnya menyerang wanita dan dapat dijumpai di seluruh dunia terutama di negara-negara berkembang (Ledger dan Witkin, 2016). Diperkirakan 70-75\% pada wanita usia subur akan menderita kandidiasis vaginalis, sekitar $\quad 40-45 \%$ mengalami infeksi berulang (Sobel, 2008; Babic dan Hukic, 2010).

Penelitian yang dilakukan Ditta bahwa Kandidiasis Vulva Vaginalis $(65,5 \%)$ merupakan diagnosis terbanyak dengan keluhan utama berupa adanya duh tubuh vagina dan rasa gatal pada 213 penderita (Harnindya, 2012). Dilaporkan dari sebuah penelitian di Puskesmas Merak Jawa Barat bahwa sebanyak 58\% ibu hamil menderita infeksi saluran reproduksi dan sekitar 9,1\% diantaranya adalah Kandidiasis vulvovaginalis (Daili, 2014). Kehamilan merupakan faktor predisposisi terjadinya kandidiasis (Prawirohardjo, 2014).

Penderita kandidiasis vaginalis umumnya ditandai dengan bercak keputihan yang tebal dengan rasa panas dan gatal yang kadang disertai dysuria (Sobel, 2007). Pemeriksaan menunjukkan bercak pada dinding vagina eritema dan edema disekitar labia dan perineum (Janik dan Heffernan, 2008).

Komplikasi kandidiasis vaginalis pada kehamilan dapat menyebabkan terjadi prematuritas, aborsi spontan, korioamnionitis dan beberapa infeksi yang dapat diderita bayi pada saat persalinan. Neonatus prematur mudah terinfeksi jamur dikarenakan sistem imun yang belum matang (Parveen et al., 2008).

Ibu hamil beresiko terjadinya kolonisasi vagina oleh Candida spp dibandingkan dengan ibu yang tidak hamil. Kehamilan mengakibatkan produksi 
estrogen meningkat dan kandungan glikogen di vagina bertambah. Hal ini mendukung pertumbuhan Candida spp. (Sobel, 2007).

Yeast yang menginvasi mukosa vagina dapat menyebabkan vulva-vaginitis, yang ditandai dengan iritasi, pruritus, dan lendir pada vagina. Kondisi ini disebabkan faktor seperti diabetes, penggunaan antibiotic, kehamilan yang mengakibatkan perubahan flora normal, keasaman dan sekresi (Horn et al, 2007). Anamnesa, dan pemeriksaan laboratorium sangat penting untuk menegakkan diagnosis kandidiasis vagina. Pemeriksaan sekret vagina dapat dilakukan dengan melakukan pemeriksaan langsung atau basah dan pemeriksaan kultur (Ramayanti, 20014; Mahon, 2015).

Pemeriksaan mikroskopik dapat dipakai untuk membuktikan adanya bentuk ragi dari Candida (Daili, 2009). Metode tersebut merupakan metode sederhana dalam pengerjaannya, dapat diaplikasikan di laboratorium mikrobiologi klinik yang sederhana dan dianggap efektif karena biaya murah dan hasil didapat dalam waktu yang singkat dibandingkan dengan kultur (Daili, 2009; Calderon, 2002).

Pemeriksaan jamur dengan pewarnaan Periodic Acid Schiff (PAS) terlihat lebih jelas daripada meng-gunakan KOH karena adanya Periodic Acid, gugusgugus hidroksil pada polisakarida kompleks dinding sel jamur mengalami oksidasi menjadi aldehida. Aldehida bereaksi dengan reagen Schiff sehingga jamur akan berwarna merah/merah muda (Murray et al, 2007).

\section{METODE}

Penelitian ini merupakan penelitian observasional deskriptif untuk mengetahui adanya kesesuaian Periodic Acid Schiff (PAS) dan $\mathrm{KOH}$ pada flour albus ibu hamil dengan pendekatan cross sectional. Populasi penelitian ini adalah seluruh spesimen sekret vagina ibu hamil yang dikirim ke laboratorium mikrobiologi klinik RSUD DR.Soetomo Surabaya. Sampel penelitian sebanyak 30 spesimen swab vagina. Pengumpulan data dari Juli-Agustus 2019.

\section{HASIL PENELITIAN}

Tabel 1. Karakteristik Demografis dan Klinis Subyek Penelitian

\begin{tabular}{|c|c|c|c|}
\hline No & Variabel & $\begin{array}{c}\text { Jum } \\
\text { lah }\end{array}$ & $(\%)$ \\
\hline 1 & Umur & & \\
\hline & $<20$ tahun & 2 & 6,7 \\
\hline & $20-35$ tahun & 21 & 70,0 \\
\hline & $>35$ tahun & 7 & 23,3 \\
\hline & Jumlah & 30 & 100,0 \\
\hline 2 & Usia Kehamilan & & \\
\hline & Preterm & 22 & 73,3 \\
\hline & Aterm & 8 & 26,7 \\
\hline & Jumlah & 30 & 100,0 \\
\hline 3 & Pendidikan & & \\
\hline & Dasar & 1 & 3,3 \\
\hline & Menengah Pertama & 21 & 70,0 \\
\hline & Menengah Atas & 6 & 20,0 \\
\hline & Perguruan Tinggi & 2 & 6,7 \\
\hline & Jumlah & 30 & 100,0 \\
\hline 4 & Pekerjaan & & \\
\hline & Bekerja & 21 & 70,0 \\
\hline & IRT & 9 & 30,0 \\
\hline
\end{tabular}




\begin{tabular}{|c|c|c|c|}
\hline & Jumlah & 30 & 100,0 \\
\hline \multirow[t]{5}{*}{5} & Gravida & & \\
\hline & Primi & 8 & 26,7 \\
\hline & Multi & 19 & 63,3 \\
\hline & Grandemulti & 3 & 10,0 \\
\hline & Jumlah & 30 & 100,0 \\
\hline \multirow[t]{4}{*}{7} & Riwayat Penyakit & & \\
\hline & $\mathrm{Ya}$ & 19 & 63.3 \\
\hline & Tidak & 11 & 36,7 \\
\hline & Jumlah & 30 & 100,0 \\
\hline \multirow[t]{4}{*}{8} & $\begin{array}{l}\text { Keluhan Flour } \\
\text { Albus }\end{array}$ & & \\
\hline & $\mathrm{Ya}$ & 15 & 50.0 \\
\hline & Tidak & 15 & 50,0 \\
\hline & Jumlah & 30 & 100,0 \\
\hline
\end{tabular}

Tabel 2. Hasil pemeriksaan PAS dan $\mathrm{KOH}$

\begin{tabular}{rrrr}
\hline & \multicolumn{2}{c}{ PAS } & \multicolumn{2}{c}{$\begin{array}{c}\text { Total } \\
(\%)\end{array}$} \\
\cline { 2 - 3 } & \multicolumn{1}{c}{ Positif } & Negatif & \\
\hline \multirow{3}{*}{$\mathrm{KOH}$ Positif } & 6 & 0 & 6 \\
\cline { 2 - 4 } & $(20 \%)$ & $(0 \%)$ & $(20 \%)$ \\
\hline \multirow{2}{*}{ Negatif } & 11 & 13 & 24 \\
& $(36,7 \%)$ & $(43,3 \%)$ & $(80 \%)$ \\
\hline
\end{tabular}

Tabel 2. menunjukkan bahwa hasil pemeriksaan Periodic Acid Schiff (PAS) pada ibu hamil dengan flour albus enam orang positif yang hasil pemeriksaan $\mathrm{KOH}$ positf. Pemeriksaan Periodic Acid Schiff (PAS) negatif dengan $\mathrm{KOH}$ positif tidak ada hasil. Jumlah hasil pemeriksaan Periodic Acid Schiff (PAS) positif sebanyak 17 orang, $56,7 \%$ diantaranya hasil pemeriksaan $\mathrm{KOH}$ positif. Jumlah ibu hamil sebagai subyek penelitian 30 spesimen sekret vagina, 20,0\% diantaranya pemeriksaan Periodic Acid Schiff (PAS) positif dengan $\mathrm{KOH}$ positif. Hal tersebut menunjukkan pewarnaan Periodic Acid Schiff (PAS) lebih baik dikarenakan struktur jamur lebih terlihat jelas karena adanya Periodic acid, gugus-gugus hidroksil pada polisakarida kompleks dinding sel jamur mengalami oksidasi menjadi aldehida. Aldehida bereaksi dengan reagen Schiff sehingga jamur akan berwarna merah/merah muda (Murray et al, 2007). Penelitian yang dilakukan oleh Rizal et al (2011) menyatakan bahwa pewarnaan Periodic Acid Schiff (PAS) memiliki sensitivitas yaitu $96,8 \%$ dan spesivisitas $20 \%$ pada 33 kasus onychomycosis. Sensitivitas 42,1\% $\mathrm{KOH}$ dan $94,7 \%$ pada 19 kasus onychomycosis (Jeelani et al, 2014).

Kultur mempunyai nilai sensitivitas yang tinggi sampai $90 \%$, tetapi hasil postif kultur saja tidak dapat dijadikan indikasi seseorang menderita kandidiasis vaginalis jika tidak ditemukan keluhan pada vagina karena $10-15 \%$ wanita normal dijumpai kolonisasi pada vagina (Daili, 2009). Hal ini didukung oleh Schorge et al (2008), kultur secara rutin tidak direkomendasikan kecuali pada wanita yang telah terinfeksi kandida sebelumnya serta gagal dalam pemberian pengobatan empiris.

Tabel 3. Hasil analisis kesesuaian pewarnaaan Periodic Acid Schiff (PAS) dan $\mathrm{KOH}$.

\begin{tabular}{lccc}
\hline & & Nilai & $\begin{array}{c}\text { Proba } \\
\text { Bilitas }\end{array}$ \\
\hline $\begin{array}{l}\text { Kesesuaian } \\
\text { pengukuran }\end{array}$ & Kappa & 0,321 & 0.017 \\
$\begin{array}{l}\text { Jumlah } \\
\text { Subyek (n) }\end{array}$ & 30 & & \\
\hline
\end{tabular}

Pada uji Kappa didapatkan nilai sebesar 0,321, yang mana hasil ini 
menunjukkan adanya kesesuaian yang buruk (poor) antara pemeriksaan jamur antara pewarnaan Periodic Acid Schiff (PAS) dan $\mathrm{KOH}$ dalam mendeteksi bentukan jamur secara mikroskopis. Nilai probabilitas adalah 0,017 atau lebih kecil dari 0,05. Hal ini berarti ukuran Kappa tersebut signifikan atau bisa dikatakan bahwa ada kesesuaian pemeriksaan jamur antara pewarnaan Periodic Acid Schiff (PAS) dan $\mathrm{KOH}$ pada flour albus ibu hamil.

\section{SIMPULAN}

Kesimpulan yang yang diperoleh dari hasil penelitian meliputi ini adalah pemeriksaan jamur secara mikroskopis dengan pewarnaan Periodic Acid Schiff (PAS) hasil total positif 17 sampel (56,7\%). Dan hasil pada pewarnaan $\mathrm{KOH}$ hasil total positif sebanyak 6 sampel (20\%). Sehingga terdapat kesesuaian pemeriksaan jamur antara pewarnaan Periodic Acid Schiff (PAS) dan $\mathrm{KOH}$ pada flour albus ibu hamil.

Saran pada penelitian ini adalah pemeriksaan mikrobiologis dengan teknik pewarnaan Periodic Acid Schiff (PAS) dapat mendeteksi lebih banyak dari $\mathrm{KOH}$. Pasien yang terdeteksi dengan hasil Periodic Acid Schiff (PAS) positif perlu dikonfirmasi dengan pemeriksaan kultur untuk menentukan jenis jamur sehingga dapat dilakukan penatalaksanaan terapi dengan tepat.

\section{DAFTAR PUSTAKA}

Babic M, \& Hukic M, 2010. Candida albicans and Non-albicans Species as Etiological Agent of Vaginitis in Pregnant and Non-Pregnant Women.Institute for Clinical Microbiology. Bosnian Journal of Basic Medical Sciences. Sarajevo;10 (1): $92-7$

Brooks G.F, Carrol C.K, Butel J.S, \& Morse S.A, 2007. Medical Microbiology. 24 ed. Mc Graw Hill. P; 642-5

Calderon R.A, 2002. Candida and Vaginal Candidiasis. American Society Microbiology Press. Washington DC. P;139-9

Daili S.F, Indriatmi W, \& Zubier F, 2009. Infeksi Menular Seksual. Edisi keempat. Jakarta: Balai Penerbit Fakultas Kedokteran Universitas Indonesia

Daili S.F, 2014. Infeksi Menular Seksual. Ilmu Kebidanan 4 th edisi. Jakarta:mP.T. Bina Pustaka Sarwono Prawirohardjo:m921-23

Dismukes W.E, 2003. Clinical Mycology. New York: Oxford University Press

Harnindya D, \& Agusni I, 2012. Departemen/Staf Medik Fungsional Ilmu Kesehatan Kulit dan Kelamin. Fakultas Kedokteran Universitas Airlangga/Rumah Sakit Umum Daerah Dr. Soetomo Surabaya: 42-43

Horn D.L, Fishman J.A, Steinbach W.J, Annaissie, E.J, Marr, K.A, Olyaei, A.J, Pfaller M.A, Weiss M.A., Webster K.M, \& Neofytos D, 2007. Presentation of The PATH Alliance registry for prospective data collection and analysis of the epidemiologi, therapy and outcomes 
of invasive tunggal infections. Diagn. Micobiol. Infect. Dis. 59, 407-414

Janik M.P, \& Heffernan M.P, 2008. Yeast Infection Candidiasis and Tinea Versicolor. In: Fitzpatrick TB. Dermatology in General Medicine 7th ed. New York: Mc.Graw Hill. Inc. pp 1822-30

Jeelani S, Ahmed Q.M, Lanker A.M, Hassan I, Jeelani N, \& Fazli T, 2015. Histopathological Examination of Nail Clipping Using PAS Staining (HPE_PAS): Gold Standard in Diagnosis of Onychomycosis. Mycoses. Hal 27-32

Juanda A, 1999. Kandidosis, Dalam: Kuswadji, Ilmu Penyakit Kulit dan Kelamin. 3th ed. Jakarta: FKUI, 1999: $106-8$

Ledger J.W, \& Witkin S.S, 2016. Candida Vulvovaginitis. 2th ed. CRC Press. New York

Mahon C.R, Lehman DC, \& Manuselis G, 2015. Textbook of diagnostic microbiology. 5th edition. Saunders Elsevier- Missouri.

Murray P.R, Baron E.J, Jorgensen J.H, Landry, M.L, \& Pfaller M.A, 2015. Manual of Clinical Microbiology, 9th ed, ASM Press, Washington DC

Murtiastutik. $2008 . \quad$ Kandidiasis Vulvovaginalis. Dalam: Barabakh J, Lumintang $\mathrm{H}$, Martodihardjo $\mathrm{S}$, editor: Infeksi Menular Seksual. Surabaya: Airlangga University Press. h. 56-64

Parveen N, Munir D.I, \& Majeed R, 2008. Frequency of Vaginal Candidiasis in
Pregnant Women Attending Routine Antenatal Clinic. Diakses 20 januari 2019: http://www.ncbi.nlm.nih.gov/pubmed $\underline{18460243}$

Prawirohardjo S, 2014. Ilmu Kandungan. Jakarta, Yayasan Bina Pustaka Sarwono Prawirohardjo

Ramayanti R, 2004. Pola Mikroorganisme Flour Albus Patologis yang disebabkan oleh infeksi pada penderita Rawat Jalan di Klinik Ginekologi Rumah Sakit Umum Dr. Kariadi Semarang. Fakultas Kedokteran Universitas Diponegoro. Diakses dari http://eprints.undip.ac.id/12387/ pada 23 januari 2019

Rizal F, Nasution A.M, \& Nasution H.L, 2010, Sensitivity and Spesificity Staining and Culture in Diagnosing Onychomycosis. Berkala Ilmu Kesehatan Kulit Kelamin, Vol 23 No 1 April 2011

Schorge J.O, Schaffer J.I, Hoffman B.L, Bradshaw K.D \& Cunningham AL, 2008. Pathogens Causing Vaginal Infection Gynecological Infection, The William's Gynecology. The McGraw Hill Companies, Inc (3):6265

Sobel J.D, 2007. Microbiology. In: Vulvovaginal Candidiasis. New York: Revan Press, LTD

Sobel J.D, 2008. Vulvovaginal Candidiasis. In: Holmes KK, editor: Sexually Transmitted Diseases. $4^{\text {th }}$ New York: Mc Graw Hill: 823-35 